\section{Whey protein contamination fiasco}

\author{
Sri Lanka Journal of Child Health, 2013; 42: 181-182
}

(Key words: Whey protein contamination; Clostridium)

The whole saga started in May 2012 when three batches of whey protein concentrate (WPC80) were produced in a manufacturing site in New Zealand ${ }^{1}$. Following suspicion that a small piece of plastic was in one of the batches, they were all re-processed at the giant Hautapu manufacturing plant in Waikato, New Zealand, where a non-sterile, little used, transfer pipe was used and the WPC80 was exposed to high levels of clostridium bacteria ${ }^{1}$. This was not known at the time and standard testing revealed no problems. The WPC80 was stored until the end of 2012, when 21.1 metric tons (MT) were sold and 17.1MT were transferred to three other Fonterra locations for further processing into consumer products ${ }^{1}$. This was completed in March 2013.

Testing carried out at the Fonterra site in Darnum, Australia in March 2013, revealed the presence of clostridia bacteria ${ }^{1}$. Product samples were put through intensive testing over the following months. On 31 July 2013, tests conducted by AgResearch (a Crown Research Institute) in New Zealand indicated the presence of Clostridium botulinum in samples from the three batches ${ }^{1}$. On August 2, 2013, Fonterra Cooperative Group Ltd. informed the Ministry for Primary Industries (MPI), the regulatory authority of New Zealand, that tests conducted by AgResearch indicated the presence of toxin-producing Clostridium botulinum in three batches of whey protein concentrate (WPC80) totaling 38.2 metric tons $(\mathrm{MT})^{1}$. While the testing for Clostridium botulinum was being carried out the tainted batches of WPC80 continued to be shipped to factories in Australia, China, Malaysia, Saudi Arabia and Thailand $^{1}$.

After an announcement to the general public on August 3rd, Fonterra instituted an extensive product recall which was complicated because WPC80 is used by Fonterra's customers in a range of products including infant formula, growing up milk powder and sports drinks, and further because the WPC80 had been sold to eight external customers for additional processing ${ }^{1}$. The result was that the potentially contaminated WPC80 was present in several thousand tons of consumer products and tens of thousands of consumer-sized packs spread over several countries ${ }^{1}$.

In Sri Lanka, the Director General of Health Services temporarily halted the release of all imported dairy products containing whey protein from the port in early August and told producers and distributors to remove all milk products and nutritional supplements containing whey protein from the shop shelves until further notice ${ }^{2}$. However, Clostridium botulinum was not detected in over 400 whey protein samples tested at the Medical Research Institute and on $22^{\text {nd }}$ August, 2013 the Ministry of Health granted approval for the release of the relevant stocks of milk powder to the market $^{2}$.

The MPI meanwhile had initiated re-testing of the WPC80 batches in question early in August at two accredited laboratories. By August 28, 2013 tests revealed conclusively that the contamination was not Clostridium botulinum but was the non-toxic strain of the same clostridia bacteria, Clostridium sporogenes ${ }^{1}$.

Clostridium sporogenes is the name given to isolates of Clostridium botulinum which do not produce toxin $^{3}$. They are considered virtually identical except for the presence of around 7 genes for botulinum toxin $^{3}$. The cheapest way to identify contaminating organisms is to isolate the microbe by growing on selective agar and then perform biochemical tests to determine species. Species can also be identified genetically by looking for particular DNA sequences like a barcode. On these kinds of tests, Clostridium botulinum \& Clostridium sporogenes would be identical $^{3}$. The next step is to determine if the strains have the capacity to produce toxins which can be done by looking for the presence of the specific genes. If positive for toxin genes, the strains are tested to see if they actually produce toxin and if that toxin is active using a mouse bioassay. The mouse bioassay could take some weeks to carry out, but the genetic identification of the presence or absence of the toxin genes can be done in hours to days ${ }^{3}$.

It appears that Fonterra alerted their customers to the presence of Clostridium botulinum in their product before confirming whether the contaminating strain 
could produce toxin and was therefore really $C$. botulinum. From a public relations point of view this was the correct decision as the backlash against Fonterra would have been severe if they had waited for confirmation of toxin production, had it proven to be positive ${ }^{3}$.

However, Fonterra was aware of the presence of clostridia bacteria in the product samples as far back as March 2013 and should have informed the MPI, which is New Zealand's regulatory authority, at this time rather than waiting till they received species confirmation by AgResearch on $31^{\text {st }}$ July 2013. Furthermore, they should not have shipped out the tainted batches of WPC80 to other countries until the Clostridium strain and its capacity for toxin production was established. These are grave errors.

The source of the bacteria has been traced to a dirty pipe in a New Zealand processing factory. This is a serious lapse in process control and should never have occurred. The New Zealand government must accept full blame for this. It was very fortunate that the bacterium turned out to be a non-toxic stain of Clostridium rather than Clostridium botulinum.

The whey protein contamination issue ultimately turned out to be a false alarm. It created a big media storm both in New Zealand and internationally but did expose some serious lapses in Fonterra's quality assurance systems and in the way the incident was handled as it progressed.

\section{References}

1. David Lee-Jones. Fonterra - Whey protein concentrate contamination issue. Available from: http://gain.fas.usda.gov/Recent\%20GAIN\%20Publica tions/Fonterra\%20\%E2\%80\%93\%20Whey\%20Protei n\%20Concentrate \%20Contamination\%20Issue Welli ngton_New\%20Zealand 9-19-2013.pdf

2. Clostridium botulinum not detected in over 400 Whey samples - MRI. Available from:

file:///C:/Users/techno/Documents/Whey\%20protein $\% 20$ issue/Clostridium\%20Botulinum\%20not\%20det ected $\% 20$ in $\% 20$ over $\% 20400 \% 20$ Whey $\% 20$ samples \%20-\%20MRI.htm

3. Fonterra's false alarm - what are Clostridium sporogenes. Posted in Science Alert: Experts respond on August 28 ${ }^{\text {th }}$ 2013. Available from:

http://www.sciencemediacentre.co.nz/2013/08/28/fon terras-false-alarm-what-is-clostridium-sporogenesexperts-respond/

G N Lucas

Joint Editor 